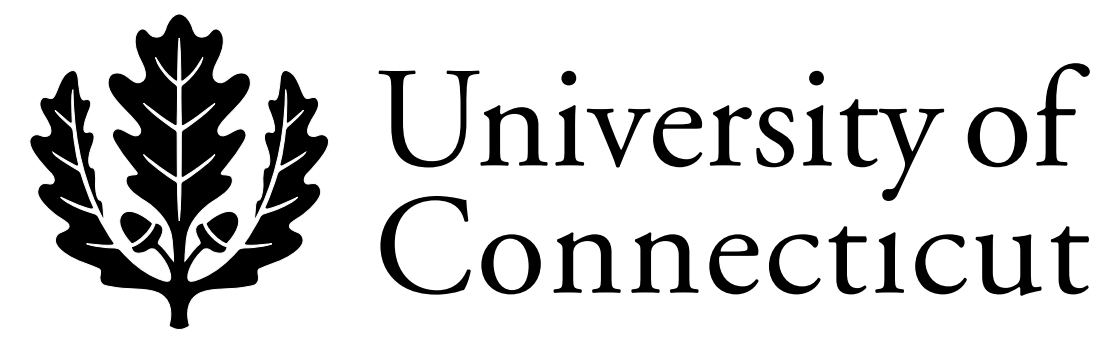

Department of Economics Working Paper Series

\title{
Ethnicity, Governance and the Provision of Public Goods
}

Mwangi S. Kimenyi

University of Connecticut

Working Paper 2003-49R

April 2003

341 Mansfield Road, Unit 1063

Storrs, CT 06269-1063

Phone: (860) 486-3022

Fax: (860) 486-4463

http://www.econ.uconn.edu/

This working paper is indexed on RePEc, http://repec.org/ 


\begin{abstract}
Ethnicity is an important institution and one that impacts on the quality of governance. This paper focuses on the behavior of ethnic groups and specifically on their impact on the provision of public goods. The paper shows that ethnic heterogeneity results in under-provision of non-excludable public goods. On the other hand, such societies associate with provision of patronage goods. The paper proposes some areas of research such the economics of ethnic institutions, empirical evidence of the role ethnic groups on public goods provision, tax compliance and institutional reforms to improve governance.
\end{abstract}

Journal of Economic Literature Classification: D70, D74, H41

This paper was prepared for presentation at the December 2003 Biannual Meetings of the African Economic Research Consortium. I am grateful to Japeth Awiti and Boaz Munga for research assistance and Germano Mwabu for comments. Nevertheless, I am the sole residual claimant to all remaining errors. 


\section{Introduction}

One of the legitimate functions of government is the provision of public goods. ${ }^{2}$ This is particularly so in the case of pure public goods-- defined as those that are non-excludable, non-rival and indivisible in production and consumption. These conditions result in a situation where the market fails to provide the goods efficiently and in sufficient quantities. Non-excludability implies that limiting access to a good or service is difficult or can be extremely costly and therefore private provision is not feasible because of the free-rider problem. Left to the market, such goods will either not be produced at all or will be under-provided. The non-rival characteristic of public goods implies that the consumption by one consumer does not reduce the quantity available to other consumers. Thus, the marginal cost of providing the good to another consumer is zero. The fact that production and consumption of a public good are indivisible implies that the good cannot be divided up and sold. Even if such goods were excludable, private provision would be inefficient since firms would charge positive prices. Governments also provide what are called impure or quasi public goods. These are goods that are only partially rival or partially excludable. While such goods could be provided by the private markets, the levels may not be efficient. By and large, markets will tend to produce those commodities with public goods characteristics in inefficiently small quantities. ${ }^{3}$

The standard assumption is that when government steps into correct for market failure, it does so with the intention of maximizing social welfare and does so efficiently. Nevertheless, government provision is itself marred by numerous inefficiencies and shortcomings--what is referred to as government failure (Buchanan and Tullock (1962) and Olson (1965). A particularly important explanation

\footnotetext{
2 Other reasons for government intervention include the existence of positive and negative externalities; income distribution and regulation of business firms where competition is not feasible. In some cases, governments engage in provision of what are referred to as "merit" goods.

3 When such goods are provided by the market, government intervention in form of regulation is often essential.
} 
for government failure is provided by the interest-group theory of government. The interest-group theory of government posits that public policy makers are not benevolent maximizers of social welfare as assumed by the market failure model but are instead motivated by self interests. In particular, policy makers seek to maximize their well-being and engage in wealth transfers in order to buy political support. Thus, well-organised redistributive coalitions advance narrow interests against a backdrop of mass "rational ignorance". This means that the political allocation that replaces market allocation is itself not efficient. In addition, public provision is subject to rent-seeking which associates with waste of resources and other inefficiencies (Tullock 1967; Krueger 1975). Other factors that explain the inefficiencies of government provision focus on the principal agent problems inherent in public provision. The principal agent problems arise form the fact that voters are not motivated to invest resources to monitor the behavior of public officials. One the one hand, public provision lacks welldefined property rights because voters are numerous and dispersed. No single individual has sufficient wealth at stake to make it worthwhile to monitor government officials on a day-to-day basis. Furthermore, the government output is often difficult to measure relative to inputs. Public employees therefore have a great deal of discretion that they exploit to advance own interest at expense of the general public (Shughart and Kimenyi 1991). All these factors undermine the quality of public provision. Because of weaker institutions of governance, these problems are more pronounced in poor countries.

A growing body of research shows that one factor influencing the quality of governance in the provision of public goods is the degree of ethnic fractionalization. In other words, other things equal, government failure associated with collective provision is more serious in societies that are more heterogeneous than those that are homogeneous. One way that ethnicity could increase the probability of government failure is by increasing the transaction costs of achieving cooperation and thus weakening institutions of governance. The literature further shows that the failure to take 
heterogeneity in the design of institutions has contributed to governance failures in countries with high degrees of ethnic fractionalization. Thus, by ignoring the importance of ethnicity in institutional design, many ethnically fractionalized developing countries are not suited to harmonize ethnic claims (Kimenyi 1998). Given the high degree of ethnic fractionalization in Africa, it is conceivable that this could be one of the reasons for poor governance in the continent. The basic premise of this paper is that ethnicity is an important institution and one that influences public policy outcomes. The paper is in the spirit of new institutional economics and basically considers ethnic groups as units of collective choice. On the one hand, ethnic groups complicate collective action translating into outcomes that make all members of the society worse off. On the other hand, ethnic units lower the transaction costs of solving prisoners dilemma problems and thus are suited to provide local public goods.

This paper is about how ethnicity impacts on governance in the provision of public goods. If in fact ethnicity does impact on the quality of governance, then such should impact on the quality and other dimensions of public provision. In the next section, the paper reviews the literature that links ethnicity to governance. Section III focuses more specifically on the impact of ethnic fractionalization on the provision of public goods and provides relevant examples in Africa. Section IV concludes with a discussion of policy implications and proposal for research agenda.

\section{Ethnicity, Governance and Collective Action}

An increasing number of studies suggest that there is a link between ethnicity and economic outcomes. A comprehensive study on ethnicity and governance by Horowitz (1985) provides an in-depth analysis of ethnicity and institutions in a wide range of countries and basically concludes that ethnicity is an important institution and one that is responsible for many outcomes observed in those societies. Horowitz also presents some proposals for institutional design that takes ethnicity into. Other authors have come to similar conclusions in terms of the importance of ethnicity as an institution. For 
example, some of the recent studies on ethnicity and institutions find that ethnically diverse societies are prone to corruption and poor governance, conflict and slow economic growth (Kimenyi 1987; Easterly and Lavine 1997; Mauro 1995; Mbaku, Ogbese and Kimenyi 2001; Kimenyi 1997). Considering the high degree of ethnic fractionalization in Africa, an understanding of how ethnic institutions impacts on collective action is crucial. This section focuses on the behavior of ethnic groups that could impact on collective provision.

One of the most striking features of African countries is the degree of ethnic heterogeneity. Sub-Saharan African countries are home to over 2,000 distinct ethnic groups that are characterized by different language, culture and traditions. The size of the ethnic groups varies from millions of people to a few hundred thousands. Heterogeneity in Africa is magnified by the wide range of religious beliefs. Another important feature of the African societies is that ethnic groups associate with a particular territory —what is referred to as geo-ethnicity. By and large, ethnic groups have what they consider to be their territory. Cobbach (1988) observes that:

In Africa, this ethnic identity is above all other things a territorial identity. Nothing defines the ethnic group better than its 'standing place'. Thus the term geoethnicity has been used to describe the African ethnic phenomenon. Geoethincity as opposed to non-territorial ethnic identification involves the historic identification of an ethnic group with a given territory, an attachment to a particular place, a sense of place as a symbol of being and identity (p. 73)

Thus, by and large, ethnic units make up what could be called "ethnic nations." Geo-ethnicity implies that provision of public goods in a particular area primarily benefits members of a distinct group. This will be true for most spatial public goods.

An important fact is that in Africa, individuals tend to associate strongly with members of their ethnic groups. Ethnic groups have through the years continued to remain distinct with members identifying strongly with their ethnic group. By and large, identifying with ones ethnic group is highly valued and resources are devoted to make certain that members of a group continue to identify with 
that group. Children are taught to identify and be proud of their tribe and ethnic identity is strongly felt and behavior based on ethnicity is normatively sanctioned (Horowitz 1985). Through this identification process, groups adopt various customs, beliefs and ways of doing things all which tend to bide the members of the group and separate them from others. More trust is nurtured amongst members of the group and in essence, members of an ethnic groups see themselves as different from others.

One of the explanations why ethnicity may impact on economic and other outcomes is simply that there are systematic differences in preferences and endowments across ethnic groups. For example, it is conceivable that preferences for a particular public good vary across different groups. If this were the case, then it can be expected that there would be differences in the desired levels and mix of public goods. Systematic differences in preferences could arise from history, custom and geography. However, the most credible explanation as to why ethnicity may impact on collective provision is through its effect on governance.

Unlike private provision, collective provision is associated with numerous governance challenges. A particular governance problem in public provision is coordination. Collective action involves various forms of transaction costs related to cooperation-that is costs of bringing people together to cooperate in organizing for the provision of a good including payment of taxes. Good governance in the provision of public goods therefore requires an institutional framework that reduces the costs of cooperation. Such an institutional framework could be supplied by experience built up through repeated interactions, a high level of social cohesion, trust or a constitutional and legal regime characterized by effectiveness and legitimacy (Meagher 2003). In essence, where interests are encompassing amongst the members of a society, transaction costs of achieving cooperation is low and collective action is enhanced. Thus, improvements in public provision require institutions that reduce the transaction costs of cooperation. 
The insight by Mucur Olson (1989) on roving and stationary bandits is particularly relevant. Traditional Chinese villages were ruled by two types of bandits. The first was a group of bandits that moved from village to village robbing and looting the produce from the farmers. Different groups of bandits would separately loot the villages in a disorganized manner. These roving bandits had not interest on the well-being of farmers as they received large benefits from plundering. In addition, plunder was seen as a common pool resource available for exploitation by the various bands. As it were, roving bandits did not undertake any investments in public goods that would have improved the well-being of the villagers and increase production. Over time, however, the regime of roving banditary was not sustainable which gave rise to stationary banditary. These were bandits who settled in the villages and monopolized rent extraction. In this case, plunder was no longer a common pool resource. Stationary bandits therefore had an interest in good economic performance (higher output) because they stood to reap those benefits. Thus, stationary bandits have an incentive to provide public goods such as a legal system, security, et. at levels that are beneficial for the economy in general. Here, encompassing interests results in cooperation that enhances public provision.

The logic of the roving and stationary bandits can be extended to explain governance in ethnically fractionalized societies (Meagher 2003). First, of course is that the quality of governance will depend on the extent of cooperation among the various social factions. More efficient governance structures will emerge where the various factions cooperate, where their shares of any inefficiencies or losses imposed by government are closer to equal, and where the number of such factions is small. Second, in the case of public good provision, the likelihood of a majority ethnic group engaging in inefficient distribution to itself or disinvestment in public good rises as the group's exclusive hold on power erodes. That is when one or more minority groups grows in number and voice posing a threat to the dominant group's hold on power and resources (Alesina et. al 1997; Batancourt and Gleason 1998). As noted by Meagher (2003), the analysis provides some idea as to the potential for 
cooperation in plural societies based on relative size and power of factions in the polity. Very small and relatively invisible minorities pose no dilemma of cooperation to the majority, perhaps because the former are too small to bear all the costs of governance inefficiencies. Factions of equal size and inclusiveness are forced to negotiate a framework of coordination to meet shared objectives.

An explanation as to why ethnicity may influence collective action and which reduces cooperation is that ethnic groups behave much like special interest groups. The interest-group theory of government as applied to ethnic groups assumes that ethnic groups seek to maximize the welfare of their members at the expense of others. Like other interest groups such as labor unions or producer groups, ethnic groups necessarily adopt strategies that give them an advantage in influencing policy decisions. The most efficient way for ethnic groups to influence policy is to capture the means of wealth transfers (that is the government). Kimenyi (1987) attributes the intense ethnic competition for political power as one of the outcomes of interest-group behavior. Unlike other interest groups, however, ethnic interest are more durable since exit and entry into such groups is limited. Thus, ethnic groups form what are referred to as 'permanent interest groups' (Kimenyi 1987). Competition amongst permanent interest groups can be expected to be more intense and continous than is the case with other interest groups. Such competition has implications on provision of public goods.

The interest-group theory of government can help explain a number of outcomes in ethnically divided countries. First of course is that there will be a tendency for the ethnic groups in power to transfer higher benefits to members of their group. In the case of public goods, it can be expected that ethnic groups that control the government will adopt those strategies that make it difficult for other groups to capture the instruments of wealth transfers. Not surprisingly, the competition to control the instruments of wealth transfers has been intense in most African countries and has been one of the underlying causes of ethnic conflicts. This analysis helps explain at least in part, the continued state of conflict and political instability in Africa where there are many ethnic groups that attempt to control 
governments. Of course such competition and ensuing conflicts impact on economic performance and also government provision.

Another governance outcome that is associated with ethnicity is corruption. A common example of how ethnic fractionalization associates with corruption relates to patronage and nepotism in the public sector. Patronage and nepotism refer to the situation of extending benefits to members of one's family, friends, or ethnic group while discriminating other people who are considered outsiders. In Africa, the most common form of corruption entails the distribution of rewards, jobs, contracts, and promotions, on the basis of ethnicity. Horowitz (1994) notes that, "in severely divided societies, ethnic identity provides clear lines to determine who will be included and who will be excluded... In ethnic politics, Inclusion may affect the distribution of important material and non material goods, including the prestige of the various ethnic groups and the identity of the state as belonging more to one group than another."(p.35).

Preferential treatment of members of one's ethnic group may primarily be a strategy to buy stability. Many African countries are under autocratic or semi autocratic rule. In these types of systems, stability of the government largely depends on maintaining a small supporting coalition intact. In other words, stability requires that the sharing coalition be small as possible. Members of other ethnic groups have the desire to remove the ruler in power and replace him with a member of their own ethnic group. Stability is therefore, a primary concern to leaders in ethnically divided societies and rulers must therefore surround themselves with trusted members of their own ethnic group. Brough and Kimenyi (1986) present a model that explains the tendency of rulers to recruit bureaucrats primarily from their own ethnic group. In this model, a ruler can increase the efficiency of the bureaucracy by appointing individuals from all the ethnic groups with the primary criteria being their competency. But such hiring practices that include members of other ethnic groups weaken the ruling coalition as benefits of the regime are shared by all ethnic groups. The result is that, by seeking to be 
efficient, the regimes risk instability. Thus, a leader faces the tradeoff between efficiency and stability. Since the most important objective of rulers is to maximize their tenure in office, then they almost always must recruit disproportionately from their ethnic groups in order to maintain the supporting coalition intact.

Figure 1 shows the choice facing a ruler of a country that has many ethnic factions. The horizontal axis shows the percentage of senior civil servants who belong to other ethnic groups other than the ruler's ethnic group. The vertical axis measures regime stability. The concave curve, SE, shows the trade-off between stability and hiring from outside the ruler's ethnic group. In this model, the higher levels of stability are achieved when top civil servants are primarily from the ruler's own ethnic group. As more and more senior servants are recruited outside the supporting coalition, stability decreases. The general assumption is that such hiring dilutes the benefits of the supporting coalition.

The percentage of senior civil servants from outside, the rulers ethnic group is determined by the tangency between the ruler's highest indifference curve and the trade-off between stability and members of other ethnic groups hired. By and large, given the desire to remain in power, leaders will tend to employ members of their own group so as to maintain the ruling coalition intact. ${ }^{4}$

More recently, Kimenyi (1997) compared ethnic groups to firms that organize for production. Each ethnic group can be considered as a monopolist faced with a downward sloping demand curve and an upward sloping marginal cost of producing "ethnic" goods. Efficient production increases the producer and consumer surplus which essentially is a measure of an ethnic group's well being. As can be expected, ethnic groups within the same country are likely to be vastly different in terms of their ability to generate surplus. Each ethnic group can increase its 'ethnic' or 'tribal' surplus by entering

\footnotetext{
${ }^{4}$ As will be seen later, this means that there is a preference for patronage goods at the expense of non-excludable goods.
} 
into mutually beneficial exchange with other ethnic groups. Thus, under conditions whereby ethnic groups are able to freely organize production and enter into market exchange with other groups, each ethnic group would seek to be efficient in production in order to increase its surplus. But efficiency in production is not the only way that an ethnic group can increase its surplus. One attractive alternative is to use the political process to capture the surplus generated by other groups. Under a system of government where taxing and spending decisions are centralized, then rulers are able to redistribute surplus from some ethnic groups to others. Given the fact that ethnic groups occupy different regions, governments are able to direct the resources to specific groups. Thus, we can expect leaders to allocate relatively larger shares of public resources to areas where members of their ethnic groups live.

A system of redistributing benefits from some groups to others could result in a number of governance issues. For one, groups that are taxpayers have an incentive to under-report and conceal their earnings. In other words, ethnicity could impact on tax compliance and consequently on public provision. Public goods are of course financed by taxes and therefore, tax compliance is an important factor in determining provision of public goods. A determinant of the extent of tax compliance is the degree of trust and cohesiveness in society. By and large, low trust societies are characterized by markedly lower levels of tax compliance than high trust societies. Experimental evidence from Social and Political Psychology has established that the level of trust and the degree of trustworthiness decreases with ethnic diversity (Zucker, 1986; Tyler, 1998; Glaeser et al., 2000; Alesina and Ferrara, 2002). Further experimental evidence has established that tax compliance increases with trust (Scholz and Pinney, 1995; scholz and Lubell, 1998a, b; Scholz, 1998). The argument given is that people are willing to comply if they know that everyone else complies. If people do not trust others to comply, they choose to evade taxes themselves. 
Tax compliance could be affected by ethnic fragmentation through social sanctions or norms. Olson (1965) argues that social sanctions can provide 'selective incentives,' in facilitating public goods provision and, therefore, as noted by Roth, Scholz and Witte (1989), social stigma associated with noncompliance could improve compliance. For social sanctions to be effective, however, it is important that individuals are affected by such sanctions. To the extent that individuals are affected mainly by social sanctions exercised by their own ethnic group, such sanctions will not be as effective in ethnically fragmented communities as in more homogeneous communities (Lassen, 2003).

Levi (1988) argues that voluntary tax compliance will occur only when taxpayers have confidence that rulers will keep their bargain and that other constituents will keep theirs. Taxpayers are strategic actors who will cooperate only when they can expect others to cooperate as well. Thus, the compliance of each depends on the compliance of others. Levi observes that voluntary tax compliance is influenced by two by social contracts. The horizontal contract (which concerns the perceived fairness of the tax payment) and vertical contract (which concerns what has been called the quid pro quo of taxation). Tax compliance largely depends on two issues: First is whether taxpayers get sufficient public goods in exchange for taxes paid. This is sometimes referred to as exchange equity (Spicer and Lundstedt, 1976). Second issue is whether taxpayers get the public goods mix they prefer. If taxpayers do not consider the benefits they get as comparable to the tax burden they bear, they will then tend to reduce their tax compliance. To the extent that leaders tend to allocate relatively more public resources to members of their ethnic group, it can be expected that other communities react by lowering their tax compliance. A secondary result is of course that overall tax revenue collections decline and thus the quality of public provision declines in ethnically fragmented societies.

Empirical evidence shows that public goods provision and participation is lower in ethnically fragmented societies (Alesina, Baqir and Easterly, 1999; Alesina and La Ferrara, 2000; Miguel, 2001). The possible reasons suggested are that different ethnic groups may prefer different public goods 
mixes and, further, that people may not want to contribute to public goods benefiting other ethnic groups. Alesina et al. (1999) argue that the lower provision is determined through the political process, as tax payers exercise their voice option. Another way through which groups can express their discontent is to use the exit option. When taxpayers feel that the public goods mix provided is much different from what they would have preferred themselves, or that the goods benefit people with whom they do not identify or that the rate of transformation is low due to pervasive corruption with much rents being appropriated by public officials and politicians, then the attractiveness of the quid pro quo contract is diminished, and there by lowering voluntary compliance to the tax code.

Ethnic groups also organize for the provision of public goods to their members. We have noted that individuals identify strongly with particular groups. For example, ethnic identification in politics is revealed by the patterns of voting. No matter which country one looks at, it has become clear that people vote very much on ethnic lines, and political ideology in the western sense rarely plays a significant role. The fact that we observe high degrees of ethnic identification implies that the expected benefits of identifying with a tribal group exceed the costs of such identification. One such benefit is the self-provision of public goods.

The strong ties within ethnic groups makes such groups ideally suited as units of collective choice that organize for public goods provision. This is because ethnicity economizes on organizational costs. In particular ethnic based institutions have a comparative advantage in solving prisoner's dilemma problems. Because members of an ethnic groups have a long-term attachment to their groups (for example, through blood or past memories), they are more likely to have continuos dealings with members of their ethnic group than with members of other ethnic groups. Continuous dealing reduces cheating in prisoner's dilemma situations and as a result ethnic groups may be more efficient in the provision of public goods than the state (Roback 1991). Simply put, within an ethnic group, cooperation is easier to elicit than when more groups are involved. The free-rider problem is 
likely to be less prevalent when the group is made up of one ethnic group than when several ethnic groups are involved. It is because of this reason that, by and large, voluntary associations in Africa almost always form along ethnic lines. In essence, ethnic groups are analogous to clubs.

Kimenyi (1998) extends the club model to ethnic provision of public goods. In the theory of clubs, individuals with similar or closely related interests cooperate in the provision of excludable public goods--club goods. Kimenyi compares ethnic groups to voluntary associations or clubs whose members have fairly homogenous preferences. Following the model of clubs as developed by Buchanan (1965), the optimal size of the club is determined by the membership at which marginal cost is equal to marginal benefit. In this model, the costs and benefits increase and decrease steadily as membership increases. Based on previous discussion, organizing collective activities by one ethnic group is expected to resemble the club model where costs and benefits increase and decrease steadily as membership increases (Figure 2). This is because the ethnic group possesses various advantages that economize on organizational costs (Landa 1994).

The benefits and costs change more dramatically when more than one ethnic group is involved (Figure 3 and 4). Organizing across different ethnic groups is more complicated and adding members from other ethnic groups creates a discontinuity in the costs and benefits. Such discontinuities result from difficulties in communicating across ethnic and linguistic boundaries and also because of differences in preferences, taste, and also because of the fact there is less trust across ethnic groups than within the same ethnic group. The implication of this club model is that ethnic groups may be suited to organize for the production of local public goods.

Rabushka and Shepsle (1972), in their analysis of multi-ethnic societies argue that ethnic salience can result in "ethnicization of collectively provided goods" in the sense that the political process allocates excludable public goods and transfers based on ethnic characteristics (favouritism). The failure of the state to insure nonexcludability make individuals turn to their ethnic communities, as 
a sort of alternative statehoods, for the provision of public goods and this process can initiate a vicious cycle in which ethnic communalism breeds attitudes of illegitimacy, which in turn reduce the effectiveness of the state, and further intensify attitudes of illegitimacy.

In summary, the foregoing discussion highlights various ways through which ethnicity may impact on the provision of public goods. The next section looks at specific on how ethnic fractionalization impacts on public provision.

\section{Ethnic Fractionalization and Public Goods}

\section{Simple Model of Public Provision}

Ethnic groups can impact on the provision of public goods in a number of ways. First, the foregoing discussion suggests that there may be systematic differences in the preferences for the quantity and type of public goods. The implication of differences in preferences across ethnic groups is that the choice of quantity and mix of public goods can be expected to vary depending on the ethnic composition of the population. This suggests that ethnic heterogeneity creates some conflict in the choice of public goods in the community. Second, ethnic groups do behave much like special interest groups that seek transfers from other groups. Interest-group behavior can impact the provision of public goods as rulers favour members of their ethnic group. Third, ethnicity tends to undermine tax compliance. Finally, the ethnic group is an important institution that economizes on the costs of achieving cooperative solutions in prisoner's dilemma situations. This means that ethnic groups can self-provide goods efficiently. Below, we discuss some of the expected outcomes in public provision given these theoretical foundations.

Consider a community with a population normalized at 1 . For simplicity, we assume that there is no entry or exit in or out of the community. The community provides public goods that are financed entirely by taxes and there are no transfers from other communities or governments. For a public 
good $g$, the voter preferences are single peaked in terms of levels of spending. ${ }^{5}$ Members of the community use majority rule to decide first on the level of taxation and then on the type and quantity of public good. Given these assumption, the most preferred choice is one represented by the median voter (Black 1958). To simplify the analysis, we assume that individuals in this community receive exogenous income $Y$ which is assumed to be the same for all members of the community. ${ }^{6}$ Thus, the disposable income for members of the community $y$ is $Y$-t.

To illustrate the impact of ethnicity on the provision of public goods, we start by presenting a simple model of public goods provision as in Alesina and Easterly (1998). The utility of members in this community can be generally expressed as $U=U(g, c)$, where c is private consumption. For an individual's disposable income $y$, then $c=(y-t)$. The public budget constraint is $g=\mathrm{t}$. Because $g$ is chosen through a preference aggregation process, the utility from $g$ to individual $i$ depends very much on the individual's preferences relative to that of the median voter.

Following Alesina and Easterly, individual preferences are as expressed as

$$
\text { 1. } \quad U^{i}=g^{a}\left(I-l_{i}\right)+y-g
$$

where $l_{i}$ is the preference distance between individual $i$ s most preferred public good and the actual public good. That is, the distance from the median voter preference. Individual $\imath$ s preferred choice of the size of the public good is obtained by solving

$$
\begin{aligned}
& \text { 2. } \operatorname{Max} U_{i}=g^{a}\left(1-l_{i}\right) y-g \text { which yields (3) } \\
& \text { 3. } g_{i}^{*}=\left[a\left(1-l_{i}\right)\right]^{1 /(1-a)}
\end{aligned}
$$

If we define $l_{1}^{m}$ as the median distance from the type most preferred by the median voter, the amount of public good provided in equilibrium is given by:

$$
\text { 4. } \quad g^{*}=\left[a\left(1-l_{i}^{m}\right)\right]^{1 /(1-a)}
$$

\footnotetext{
${ }^{5}$ Single peaked preferences simplify the analysis as majority cycling is avoided.

${ }^{6}$ The assumption of equal income helps in isolating differences in incomes associated with income. By assuming same income, we are left with differences in preferences only due to ethnicity.
} 


\section{Provision of Non-excludable goods}

From the result in equation 4, it is possible to draw some conclusion relating to the public provision and population characteristics. First, it is evident that the equilibrium amount of public good provided decreases with the median distance from the median. Given that individual first vote on the amount of tax, the larger the median distance from the median voter, the lower the level of g. In other words, in communities with widely varying preferences, individuals will prefer lower taxes (smaller quantities of public goods) and instead devote more resources to private consumption.

Figure 5 depicts preferences of particular public goods by different ethnic groups, $E_{a} E_{b} E_{c}$ and $E_{d}$. These are the quantities of public goods that the different ethnic groups would prefer. Consider a case where there are only two ethnic groups, $E_{a}$ and $E_{b}$. The preferences of the two groups are very different with $E_{a}$ preferring a much lower level of $g$ whereas $E_{b}$ prefers a much larger quantity. In this polarized community, the "median distance from the median" is large. Public provision in the society is likely to result in outcomes that are sub-optimal from the perspective of each of the groups. The tendency then would for the ethnic groups to opt for lower taxes and thus lower amounts of the nonexcludable good. On the other hand, a community comprised of only $\mathrm{E}_{\mathrm{c}}$ and $\mathrm{E}_{\mathrm{d}}$ is likely to have higher quantities of public good as the median distance from the median is relatively small as compared to the case of $\mathrm{E}_{\mathrm{a}}$ and $\mathrm{E}_{\mathrm{b}}$. In other words, $\mathrm{c}$ and $\mathrm{d}$ are likely to agree on the quantities of the public good to be provided.

Ethnic conflicts over the provision of public goods could arise from the fact that different ethnic groups live in different territories within the same country as discussed earlier. In this case, the benefits of a public good vary across ethnic groups. Thus, ethnic groups are likely to oppose provision of public goods whose benefit largely accrues to others. The basic conclusion is that ethnic fragmentation lowers the amount of resources devoted to non-excludable public goods. 


\section{Patronage goods}

Previous discussion highlighted the interest-group behavior of ethnic groups. Ethnic groups compete to control the state in order to transfer benefits to members of their group. To the extent that nonexcludable goods are likely to benefit all groups, they are not suitable vehicles to concentrate benefits on any one particular group. Thus, governments in ethnically fractionalized societies are likely to reduce spending on non-excludable goods and instead allocate more resources to "excludable" goods that can be targeted to particular groups or individuals. A good example of such spending is on public employment of members of a particular ethnic groups or targeted transfers to members of a community. We refer to these targeted benefits as patronage goods (Kimenyi and Shughart 1989; Alesina and Easterly 1998).

Let total spending $G$ be composed of two goods- $g_{1}$, non-excludable goods and $g_{2}$, patronage goods. Provision of $g_{1}$ benefits all ethnic groups while $g_{2}$ benefits only selected grops. The ratio $g_{1} /\left(g_{1}+g_{2}\right)$ will therefore vary with the degree of ethnic polarization. The more polarized the society, the higher the share of $\mathrm{g}_{2}$. In other words, polarization leads to a reduction in the share of non-excludable public goods to the total spending.

\section{Ethnic Provision of "club goods"}

The foregoing discussion points to inefficiencies in the provision of public goods arising from ethnic fractionalization. But the previous discussion also demonstrated that ethnic groups are important institutions that reduce the transaction costs of reaching cooperative outcomes. In other words, ethnic groups have advantage in solving prisoner's dilemma situations that otherwise complicate collective provision. At one level, ethnic provision of public goods is the result of marginalization by a dominant group. At another level, ethnic provision is desirable because the cost of organizing collective provision increases rapidly as more ethnic groups are involved. In essence, as cooperation weakens, 
public provision deteriorates. Another way of looking at this is the situation where ethnic preferences for a public good are quite different as shown in Figure 6. In this case, the two ethnic group's preferences are represented by A and B with a bimodal distribution, The median voter outcomes for the two are $\mathrm{A}^{*}$ and $\mathrm{B}^{*}$. Given this distribution of preferences, decentralized provision would be best for the two groups.

\section{Evidence}

Some of the more comprehensive studies on how ethnic groups impact on public provision have focused on blacks and whites in the United States of America. Earlier studies focused on the provision of education and particularly the impact of while flight. ${ }^{7}$ One of the triggers for white flight was in the South following the striking down of dejure segregation following the Brown Versus Board of Education decision in 1954. In this landmark court case, the Supreme Court of the United States declared that separate education facilities were inherently unequal and thus made racial segregation illegal. ${ }^{8}$ During the era of segregation, whites and blacks attended different public schools. Nevertheless, those attended by blacks were largely inferior-poorly funded and poorly trained teachers, infrastructure, etc. In this case, public provision varied across the ethnic groups purely because of racial discrimination. After the High Court ruled against the segregationists, whites exited from public schools in large numbers and joined private schools. The while flight was particularly evident in those localities that had higher populations of blacks (Conlon and Kimenyi 1990 ). Given that whites were also the ones primarily making decision on resource allocation, one of the outcome of white flight was a marked reduction in funding of public schools generally. The other wave of white flight was triggered by the

\footnotetext{
${ }^{7}$ White flight is used to refer to the wholesale migration of whites in communities or schools as the population of blacks increases.

8 The idea of "separate and Equal" was entrenched following the Plessy V. Fergusin decision by the Supreme Court in 1896.
} 
migration of blacks into the urban centers from rural south. As more blacks moved in, whites exited into the suburbs. There was again subsequent deterioration in the quality of public provision in urban centers populated by blacks. To a large extent, the differences in public goods following white flight were largely the result of a diminished tax base due to low incomes but also because of reduced transfer to these localities.

More recent studies show that ethnic diversity impacts on the provision of public goods in the United States. Alesina, Bagur and Easterly (1999), find that higher levels of ethnic diversity associate with low levels of provision of public goods across U.S. Municipalities. Specifically, they find that high levels of ethnic diversity are associated with up to $25 \%$ lower funding for public schools. Below, we provide evidence that links ethnicity to public goods provision in Africa.

\section{Provision of non-excludable public goods and Patronage goods}

Unfortunately, there are not many empirical studies that have focused specifically on the impact of ethnicity on provision of public goods in Africa. The evidence available is basically of two types. The first looks directly at the impact of ethnic diversity on a particular public good such as education. The second approach looks at how ethnicity influences the allocation of public resources.

In a study on the impact of ethnic diversity on school funding by communities in Western Kenya, Migue (2000), finds that higher levels of local ethnic diversity to be associated with sharply lower primary school funding and much poorer school facilities. The community studied by Miguel is in Busia and Teso Districts and is ethnically diverse with $67 \%$ of the population being Luhya, 26\% Teso and 5\% Luo. Figure 7 shows what happens to school funding as the population mix changes. As is evident, the level of funding is much higher when the communities are homogeneous and lowest when the communities are of almost ethnically diverse. This evidence is quite consistent to the theoretical proposition that ethnic diversity will result in lower funding of public goods. Miguel concludes that: 
Ethnic diversity is associated with sharply lower local school funding and worse school facilities in rural Western Kenyan primary schools. Ethnic diversity across tribes rather than across subtribes appears to be driving this negative relationship, suggesting that collective action problems may be more severe in the presence of greater cultural and linguistic differences. Donations from local fundraisers (harambees) — events that require considerable community coordination and participation to be successful—are sharply lower in ethnically diverse areas. Given the central role that harambees play in Kenya local public finance, the results of this paper suggest that local ethnic diversity may be negatively associated with the provision of other local public goods in Kenya (p. 30).

The discussion in the previous section alluded to the fact that one of the key issues is that leaders in ethnically heterogeneous societies tend to allocate relatively more of a nations resources to regions where members of their ethnic group reside. Brockerhoff and Hewett (1998) investigate whether dominance of national political authority (by an ethnic group) confers advantages to members of the ethnic group. The authors mainly make use of data from demographic and health surveys (DHS) between 1990 and 1995. They begin with the premise that members of ethnic groups enjoy more favorable conditions even outside urban areas as a result of nonrandom placement of resources or uneven economic development patterns among the groups. They conclude that the dominant elite may have channeled scarce state resources to areas where members of their ethnic groups are concentrated.

Table 1 shows the leadership of a number of African states focusing on ethnic political dominance. The selected states are relatively stable and have had prolonged periods of political dominance by one or two ethnic communities. The purpose is to investigate the extent to which political dominance by an ethnic group influences public resource allocation. By and large, for the 11 selected countries results show public provision is significantly higher among groups that have had high-level government representation than among other groups for example in terms of road infrastructure, access to public health services and education (Tables 2 and 3). In Mali, Niger and Senegal, for example, complete immunization coverage is significantly higher among groups that have had high-level government representation than among other groups. Among the Serer of Senegal a 20 
percent survival disadvantage around 1970 was reversed to a 20 percent advantage by around 1990 . This is despite the fact that the Serer are disproportionately concentrated in rural areas of Senegal (Pison et al 1995). In rural Senegal, the median distance to a health facility is $34 \mathrm{~km}$ for Serers as compared to an average distance of $61.9 \mathrm{~km}$ for other ethnic groups. The Bambara and DjermaSonghai are much more likely than others to live in rural communities that are served by all weather surfaces and in Ghana, 84 percent of Ashanti received some education, as compared to about 60 percent of others ethnic groups. In Niger, women who belong to the Djerma and Songhai are twice as likely to have attended school, as are other women. Similar advantages are noticeable among groups that have dominated political leadership such as the Baoule of Cote d'Ivore, Kikuyu of Kenya and the Bemba of Zambia. Other evidence show that, in Kenya the Kalenjins enjoyed a decline (in child mortality) of 37 percent between cohorts 1978-82 and 1983-87, coinciding with Moi's consolidation of power (Ungar, 1986). Child mortality levels of the Kikuyu were at par with those of many industrialized countries of the North by the 1980's (UNICEF, 1997). The under five mortality rate during 1989-93 was 36.1 for the Kikuyu and 125.1 for the non-Kikuyu in Kenya.

Kenya is a good example of how rulers serve ethnic interests through patronage goods. Since independence, Kenya has had only three presidents: Jomo Kenyatta, who ruled from 1963 until his death in 1978; Daniel Arap Moi who ruled from 1978 to December 2002, and Mwai Kibaki who became President in 2002. The First two presidents came from different ethnic groups each having a different support base. The evidence available, strongly supports the idea that resource allocation in Kenya has been determined more by political and ethnic consideration than by actual needs of the population or established criteria of economic efficiency. Likewise, the appointment of senior civil servants is largely influenced by ethnicity.

During Kenyatta's era, the Kenyan cabinet was relatively small, but his ethnic group was over represented. This was also true for all senior civil servants, police force and the military. Upon taking 
power, President Moi increased the number of cabinet positions and the civil service awarding the positions to members of his ethnic group and other ethnic groups from his home province. At the same time, he deliberately removed members of the cabinet and senior civil servants belonging to Kenyatta's ethnic group. Within a relatively short period of time, Moi had been able to totally change the ethnic representation of the cabinet and the bureaucracy. Accompanying these changes, government spending increased rapidly as the new President made concerted efforts to distribute benefits to members of his ethnic group and pay the bloated civil service. Table 4 shows the change in the composition of the Kenyan cabinet following Moi's rise to the presidency. The evidence here again supports the previous discussion that rulers in Africa award senior positions to primarily, members of their own ethnic group. This is a clear example of provision of patronage goods. Likewise, the case of Burundi where the Tusti are dominated politics clearly reveals similar trends. Despite the fact that the Hutus are the majority, they are hold few positions in the civil service of that country (Table 5 and6 6). This evidence points to the fact hat allocation of excludable public goods is influenced significantly by ethnic dominance in political leadership.

\section{Ethnic Self-Provision of Public Goods}

The discussion above shows that in ethnically fractionalized societies, we can expect a bias against provision of non-excludable goods in favor of patronage goods. Governments intervene to extract resources but only transfer to select individuals or communities. Because of the vacuum so left by the state, ethnic groups organize to provide themselves with public goods. This is consistent with the idea of absent-present state advanced by (Reddy 2001).

Reddy (2001, p. 296) argues that there is a "link between constructions of ethnic identities and the ideology and character of authoritarian, despotic or oppressive states." Such states are usually both absent and present. At one level, they "are highly intrusive and extractive. At another level, these states 
are absent, failing to supply adequate or any welfare benefits, health, education, protection, justice, national identity and so on." Such state absence forces individuals to rely on their ethnic groups for essential public goods and services (e.g., protection of self and property; education, health care; etc.).

In a country with a fully functioning democratic and representative government, local interests are articulated at the national level by elected representatives. However, in authoritarian one-party and military regimes, such as those that emerged in the African countries in the 1960s and 1970s, ethnic organizations, particularly the "home town" associations came to represent the main (and in some cases, the only) instrument for the articulation of local interests. These voluntary organizations not only came to represent an important conduit through which local objectives were articulated at the national level, but also served as the primary development agency for many villages and regions in the African countries. In fact, it was through such organizations that Africans in the urban areas and the Diaspora contributed to development in their villages and regions of origin. In the process, the home town association has had a significant impact on governance and the allocation of resources in many African countries.

In most African countries, home town associations are voluntary organizations designed to provide mutual benefits for their members. In Cameroon and Nigeria, for example, hometown associations have been formed by urban residents and those in the Diaspora (notably in the United States and Western Europe) for the promotion of social and economic development in their "ancestral" regions. In fact, through these organizations many "sons and daughters" of several villages in Cameroon currently living in the Diaspora have been able to provide health care, educational and water facilities for their kin back home. According to Barkan, McNulty and Ayeni (1991, p. 462), home town associations in Côte d'Ivoire have provided

An array of basic services to residents of local communities-primarily and especially secondary schools; medical services through the construction and staffing of health clinics and even hospitals, electricity and telephone lines through the installation of utility poles, roads, 
public meeting halls, and postal services through the construction of the necessary infrastructure.

Schools, medical facilities, public utilities, and roads are all social overhead capital that should be provided by the government. However, in the case where the state is absent, many ethnic-based nongovernmental organizations have stepped in to provide these critical infrastructures. As argued by Reddy (2001), ethnic-based associations were very critical to the survival of blacks under the apartheid regime, which came into being in South Africa in 1948. Where the state refused to provide essential services to the people, ethnic associations stepped in to feel the void. In the case where the state provided inferior services or those that were considered detrimental to the welfare of the black population (e.g., medical services provided by poorly trained personnel; education designed to prevent blacks from acquiring the skills they needed to become competitive with whites in the labor force, etc.), ethnic associations quite often came to the rescue and established structures for the provision of alternative services.

Many of these ethnic-based associations usually have broad mandates, with social and economic development, including the provision of essential social services (which, ordinarily are provided by the government), as their main focus. However, the nature and kinds of activities that these organizations engage in is determined, to a large extent, by the nature of government provision. In some African countries where the ruling party uses public provision to gain votes and maintain its hold on power, ethnic groups and regions that support the opposition are deprived of essential public services, including social overhead capital for development. Many of these associations provide water, health care, education (especially at the primary level), HIV/AIDS prevention instruction, including the distribution of condoms, and other services, which are usually the purview of formal government.

\section{Conclusion: Proposals for research}


The general message of this paper is that ethnic diversity influences the provision of public goods. Theory points to the fact that ethnic fragmentation largely results in under provision of public goods. Such under provision can in turn lead to underdevelopment. Unfortunately there is only limited research that have empirically looked at how ethnicity impacts on public provision. A number of research issues are proposed for additional research.

(a). Economics of Ethnic institutions: A lot of discussions on ethnic groups lack systematically articulated theoretical foundations of the behaviour and organization of such groups. One area of research that could help improve the understanding of outcomes in ethnically fragmented countries is to model ethnic groups as institutions for collective action. In other words, such research should be able to provide clear insights of the behaviour of ethnic groups and expected outcomes under different environments.

(b). Empirical evidence of public goods provision: As observed previously, empirical evidence on ow ethnicity impacts on public goods provision is scarce. This is a fruitful area of research that could add value to the current understanding of ethnicity.

( c ). Tax Compliance: Theory points to low tax compliance in ethnically fragmented societies. However, there is limited evidence to support such assertions. Cross country and cross community studies could shed some light on how ax compliance is impacted on by ethnic diversity.

(d). Institutional Reforms: The implication of the results reported in this paper is that ethnic fragmentation is not good for development. It lowers trust, tax compliance, is associated with ethnic rent-seking, inefficient wealth transfers and an overall under-provision of public goods. But ethnic heterogeneity I a given and cannot be wished away. The issue then is to study institutional reforms that could reduce the adverse consequences of ethnicity. 


\section{References}

Agbese, P. O. (1992), "With Fingers on the Trigger: The Military as Custodian of Democracy in Nigeria," Journal of Third World Studies, Vol. 9, No. 2, pp. 220-253.

Alesina, A. and La Ferrara, E. (2002), "Who Trusts Others?” Journal of Public Economics, 85: 207-234.

Alesina, A. and Rodrik, D. (1994), "Distributive Politics and Economic Growth," Quarterly Journal of Economics, 109: 465-490.

Alesina, A. and La Ferrara, E. (2000), "Participation in Heterogeneous Communities," Quarterly Journal of Economics, 115: 847-904.

Alesina, A. Baqir, R. and Easterly, W. (1999), "Public Goods and Ethnic Divisions," Quarterly Journal of Economics, 114: 1243-1284.

Alesina, A. Baqir, R. and Easterly, W. (1998). Redistributive Public Employment," Mimeo.

Annet, A. (1997), "Ethnic and Religious Divisions, Political Instability, and Government Consumption," Mimeo, Department of Economics, Columbia University.

Bates, R. H. (1999), "Ethnicity, Capital Formation, and Conflict," CID Working Paper No. 27 (Cambridge, MA: Center for International Development, Harvard University).

Betancourt, R. Gleason, S. (1998), "The Allocation of Publicly-Provided Goods to Rural Households in India: On some Consequences of Caste, Religion and Democracy," IRIS Working Paper \#217, University of Marlyland.

Black, D. (1958). The Theory of Committees and Elections. Cambridge: University Press.

Brough, W. and Kimenyi, M.S. (1986), "On the Efficient Extraction of Rents by Dictators," Public Choice,

Buchanan, J.M. (1965), “An Economic Theory of Clubs,” Economica, 32:1-14.

Buchanan, J. M. and Tullock, G. (1962). The Calculus of Consent. Ann Arbor: University of Michigan Press.

Conlon, J. and Kimenyi, M. S. (1991)), "Attitudes Toward Race and Poverty in the Demand for Private Education: The Case of Mississippi," Review of Black Political Economy, Fall, 6-22.

Decalo, S. (1992), "The Process, Prospects and Constraints of Democratization in Africa," African Affairs, Vol. 9, No. 362, pp. 7-35.

Easterly, W. and Levine, R. (1997, "Africa's Growth Tragedy: Policies and Ethnic Divisions”, The Quarterly Journal of Economics, (November): 1203-1250.

Glaeser et al. (2000), "Measuring Trust," Quarterly Journal of Economics, 115: 811-846.

Gwartney, J. D. and Wagner, R. E. (1988), "Public Choice and the Conduct of Representative Government," in Gwartney, J. D. and Wagner, R. E. (eds.), Public Choice and Constitutional Economics (Greenwich, CT: JAI Press).

Horowitz, D. (1985). Ethnic Groups in Conflict. Berkeley: University of California Press.

Ihonvbere, J. O. and Ekekwe, E. (1988), "Dependent Capitalism, Structural Adjustment and Democratic Possibilities in Nigeria’s Third Republic," Afrika Spectrum, Vol. 23, No. 3, pp. 273292.

Knack, S. and Keefer, P. (1997), "Does Social Capital Have an Economic Payoff?: A Cross-Country Investigation," Quarterly Journal of Economics, 112: 1251-1288.

Kimenyi, M.S. (1987), "Bureaucratic Rents and Political Institutions," Journal of Public Finance and Publlic Choice, 3: 189-200.

Kimenyi, M.S.. (1989), "Interest Groups, Transfer-Seeking and Democratization: Competition for Benefits of Governmant Power May Explain African Political Instability," American Journal of Economics and Sociology, 48: 339-49. 
Kimenyi, M. S. (1995). Economics of Poverty, Discrimination and Public Policy. Cincinnati: South-Western Publishers.

Kimenyi, M. S. (1998), "Harmonizing Ethnic Claims in Africa: A Proposal for Ethnic-Based Federalism," Cato Journal, Vol. 18, No. 1 (Spring/Summer), pp. 43-63.

Kimenyi, M. S. and Mbaku, J. M. (1993), "Rent Seeking and Institutional Stability in Developing Societies," Public Choice, Vol. 77, No. 2, pp. 385-405.

Kimenyi, M. S. and Shughart, W. F. (1989), "Political Successions and the Growth of Government," Public Choice, 62:173-179.

Krueger, A. (1975), "The Political Economy of the Rent-Seeking Society," American Economic Review, 64: 291-203.

Landa, J.T. (1994), Trust, Ethnicity and Identity. Ann Arbor: University of Michigan Press.

Lassen, D. D. (2003), "Ethnic Divisions and the Size of the Informal Sector," Economic Policy Research Unit, University of Copenhagen, mimeo.

Levi, M. (1988), Of Rule and Revenue. Berkeley: University of California Press.

Mbaku, J. M. and Kimenyi, M. S. (1995), "Democratization in Africa: The Continuing Struggle," Coexistence, Vol. 32, pp. 119-136.

Mbaku, J. M. (1997), Institutions and Reform in Africa: The Public Choice Perspective (Westport, CT: Praeger).

Mbaku, J. M. (1999), "Making the State Relevant to African Societies," in Mbaku, J. M. (ed.), Preparing Africa for the Twenty-First Century: Strategies for Peaceful Coexistence and Sustainable Development (Aldershot, UK: Ashgate).

Mbaku, J. M. (2001), "Ethnicity, Constitutionalism, and Governance in Africa," in Mbaku, J. M., Agbese, P. O., and Kimenyi, M. S. (eds.), Ethnicity and Governance in the Third World (Aldershot, $\mathrm{UK}$ : Ashgate).

Mbaku, J. M. (2002), “Cameroon's Stalled Transition to Democratic Governance: Lessons for Africa's New Democrats," African and Asian Studies, Vol. 1, No. 3, pp. 125-163.

Mbaku, J.M., Ogbese, P. O. and Kimenyi, M.S. (Eds), (2001). Ethnicity and Governance in the Third World, Aldersho: Ashgate Publishers.

Meagher, P. (2003), "Institutiotnal Design and the Governance challenges of Plural Societies," Working Paper, University of Maryland, IRIS.

Mehta, P. B. (1998), "Ethnicity, Nationalism and Violence in South Asia," Pacific Affairs, Vol. 71, No. 3, pp. 337-396.

Miguel, E. (2000), "Ethnic Diversity and School Funding in Kenya," Mimeo, University of California at Berkely.

Miguel, E. (2002), "Tribe or Nation?: Nation-Building and Public Goods in Kenya Versus Tanzania," Mimeo, University of California at Berkely.

Nagel, J. (1995), "Resource Competition Theories," American Behavioral Scientist, Vol. 38, No. 3 (January), pp. 442-458.

Olson, M. (1965). The Logic of Collective Action. Cambridge: Harvard University Press.

Olson, M. (1993), "Dictatorship, Democracy and Development," American Political Science Review, Vol. 87: 567-576.

Rabushka, A. and Shepsle, K. A. (1972), Politics in Plural Societies: A Theory of Democratic Instability, Columbus: Charles E. Merrill Publishing Company.

Reddy, M. (2001), "Ethnic Conflict and Violence: South Africa, Punjab and Sri Lanka," in Mbaku, J. M., Agbese, P. O. and Kimenyi, M. S. (eds.), Ethnicity and Governance in the Third World (Aldershot, UK: Ashgate).

Roback, J. (1991). "Plural but Equal: Group Identity and Voluntary Integration," Social Philosophy and Policy, 8(2): 60-80. 
Roth, J. A., Scholz, J. T. and Witte, A. D. (1989), Tax Compliance, Philadelphia: University of Pennsylvania Press.

Scholz, J. T. and Pinney, N. (1995), "Duty, Fear, and Tax Compliance: The Heuristic Basis of Citizen Behaviour," American Journal of Political Science, 39: 490-512.

Scholz, J. T. and Lubell, M. (1998a), "Adaptive Political Attitudes: Duty, Trust, and Fear as Monitors of Tax Policy," American Journal of Political Science, 42: 903-920.

Scholz, J. T. and Lubell, M. (1998b), "Trust and Taxpaying: Testing the Heuristic Approach to Collective Action," American Journal of Political Science, 42: 398-417.

Scholz, J. T. (1998), “Trust, Taxes, and Compliance” In Trust and Governance, ed. Braithwaite, V. and Levi, M., New York: Russell Sage Foundation, pp. 269-294.

Spicer, M. W. and Lundstedt, S. B.(1976), “Understanding Tax Evasion,” Public Finance, 31:295-305.

St. Jorre, J. (1972), The Nigerian Civil War (London: Hodder and Stoughton).

Tullock, G. (1967). “ The Welfare Costs of Tariffs, Monopolies and Theft," Western Economic Journal, 5, 224-32.

Tyler, T. R. (1998), “Trust and Democratic Governance” In Trust and Governance, ed. Braithwaite, V. and Levi, M., New York: Russell Sage Foundation, pp. 269-294.

Welsh, D. (1971), Roots of Segregation: Native Policy in Colonial Natal, 1845-1910 (Cape Town: Oxford University Press).

Woods, D. (1994), "Elites, Ethnicity, and 'Home Town' Associations in the Côte d'Ivoire: An Historical Analysis of State-Society Links." Africa, Vol. 64, No. 4, pp. 465-483.

Zucker, L. G. (1986), "Production of Trust: Institutional Sources of Economic Structure, 1840-1920" In Research in Organizational Behaviour, ed. Barry, M. S. and Cummings, L. L., Greenwich, CT: JAI Press pp. 53-111. 
Figure 1: Ethnicity, stability and efficiency

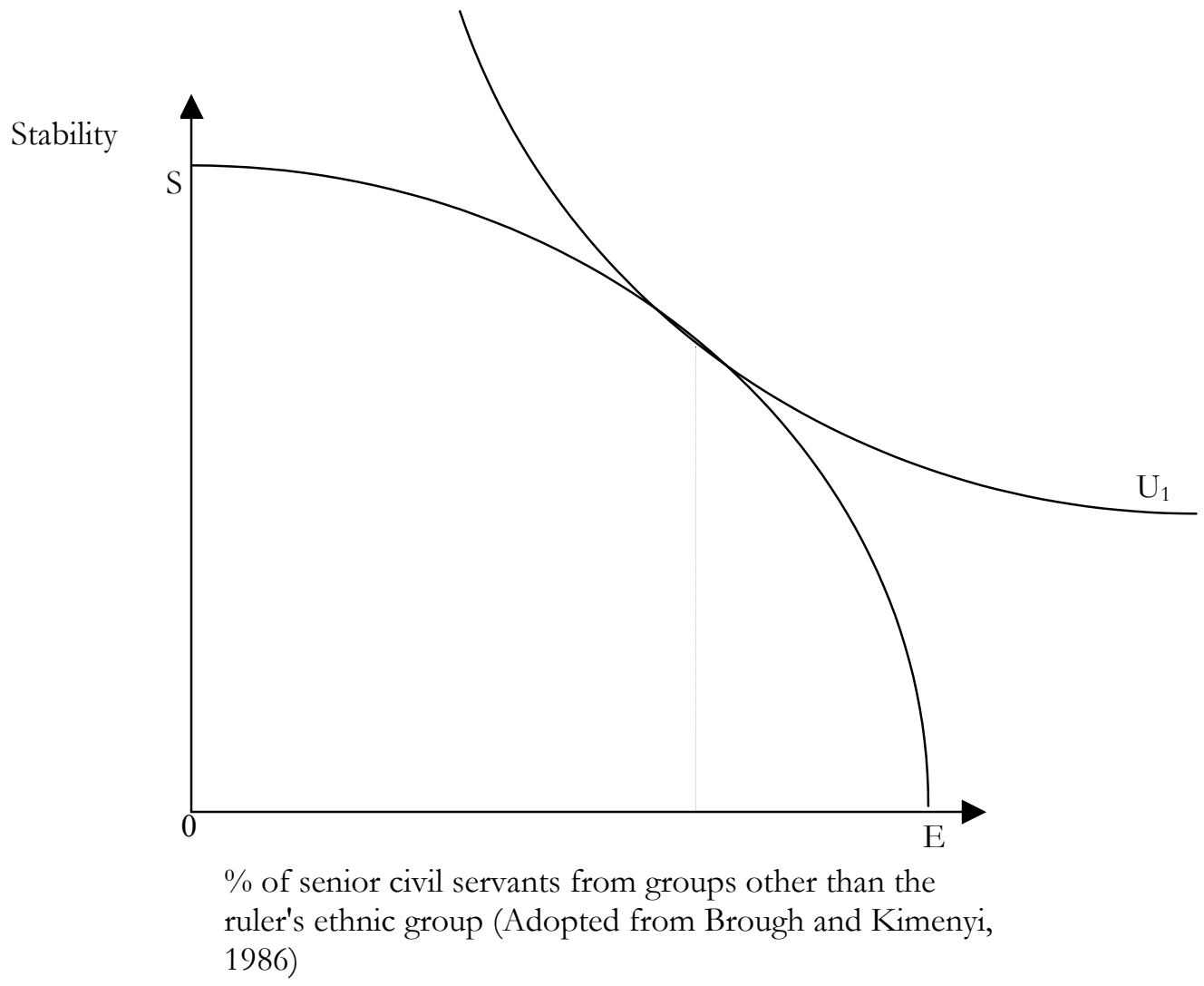


Figure 2: Optimal size of a club

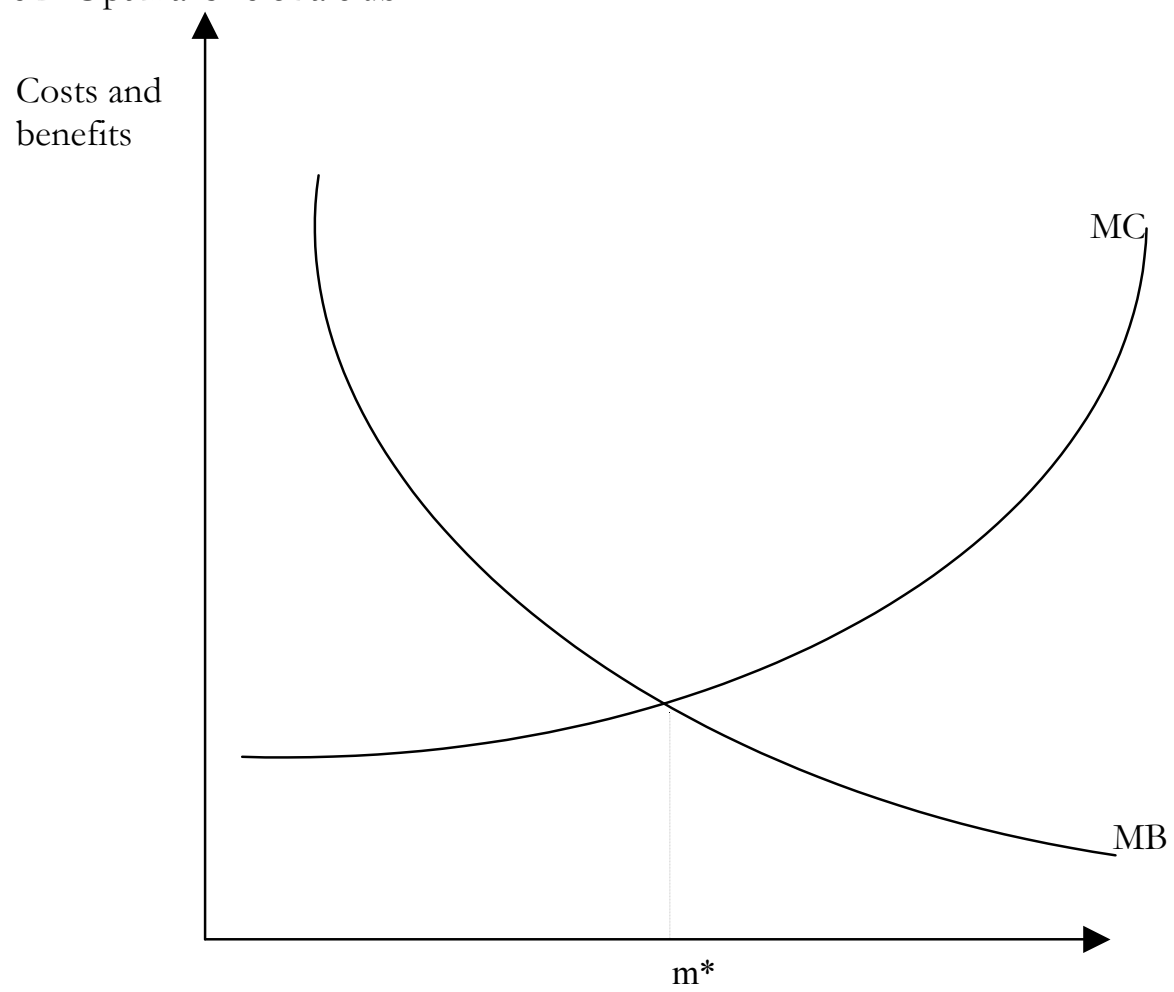

Figure 3: Ethnicity and collective provision Members

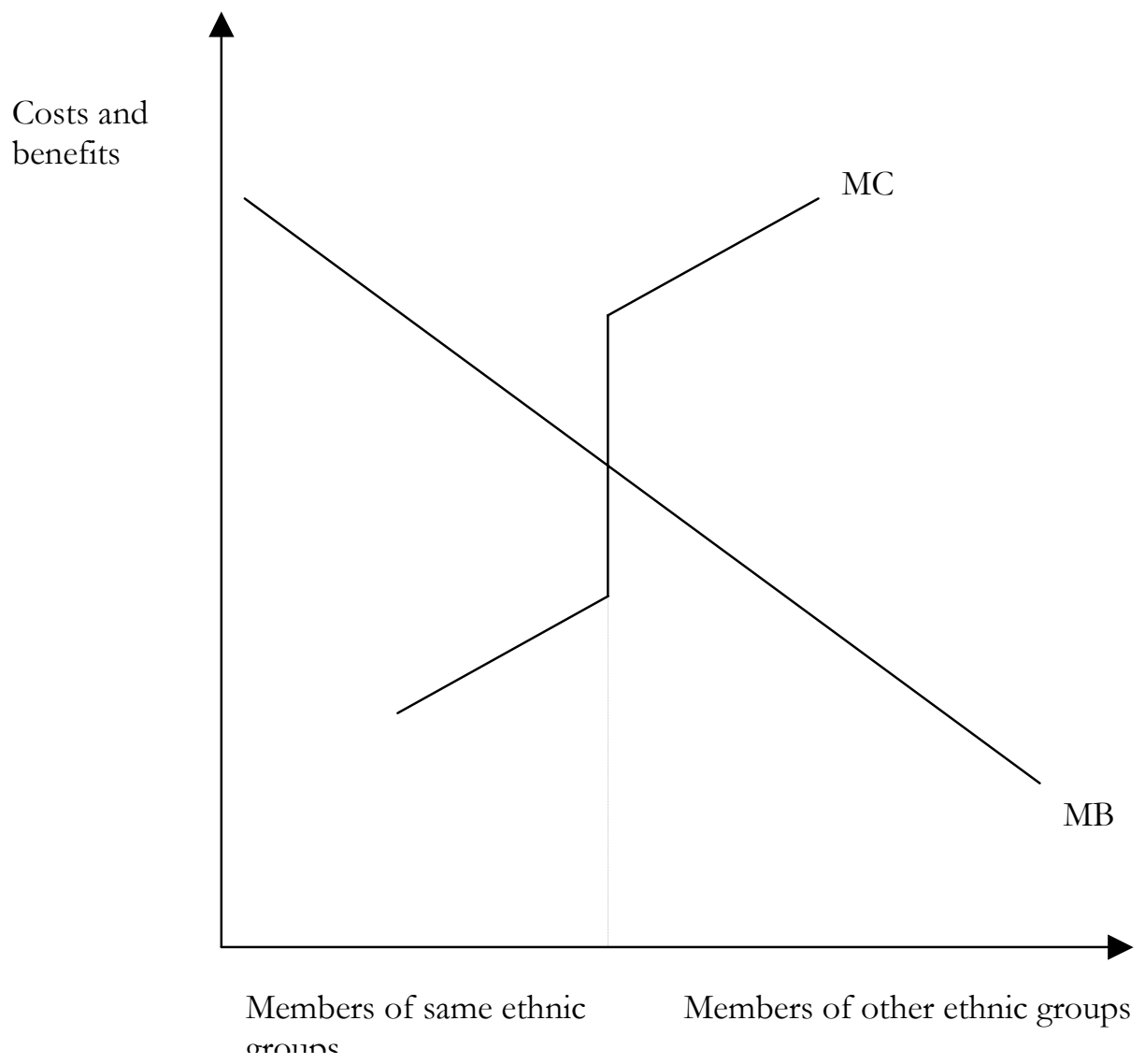


Figure 4: Ethnicity and collective provision

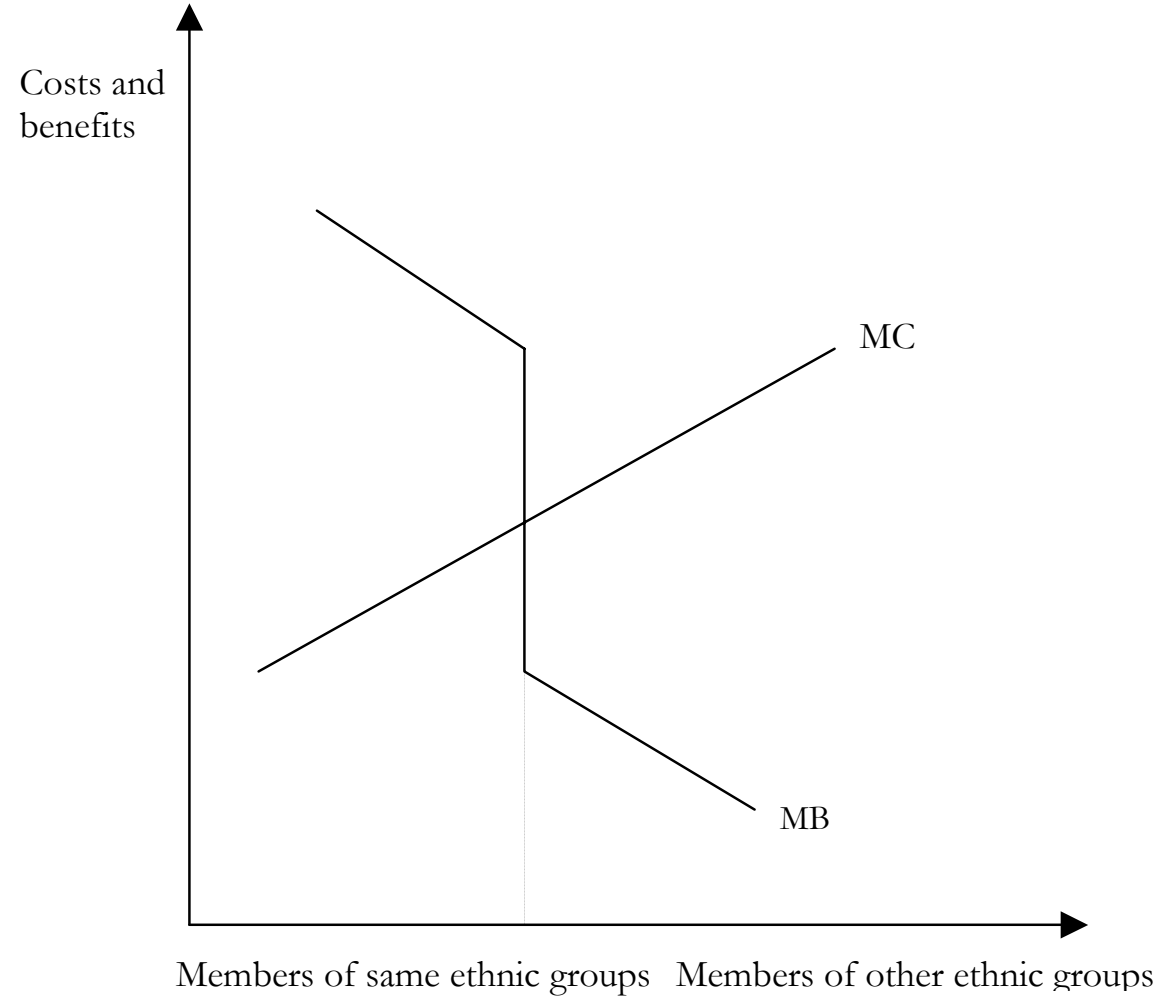

Figure 5: Preferences for a public good by different ethnic groups

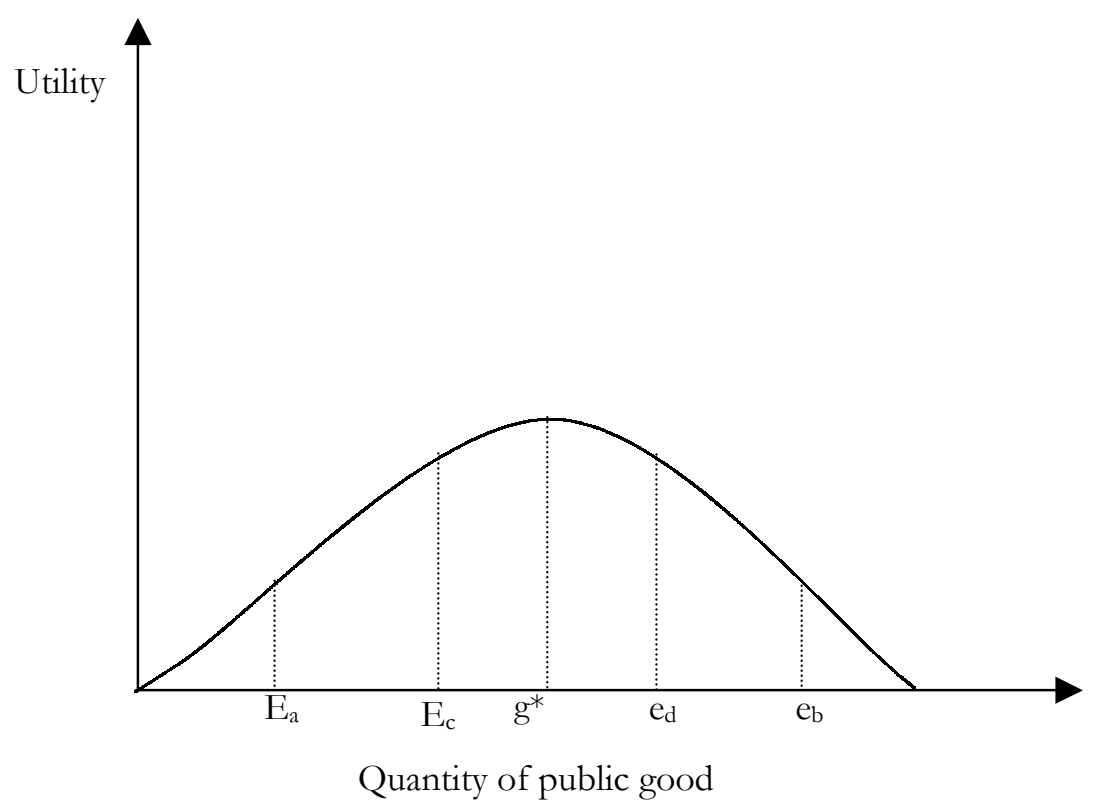


Figure 6: Preferences for a public good by two ethnic groups

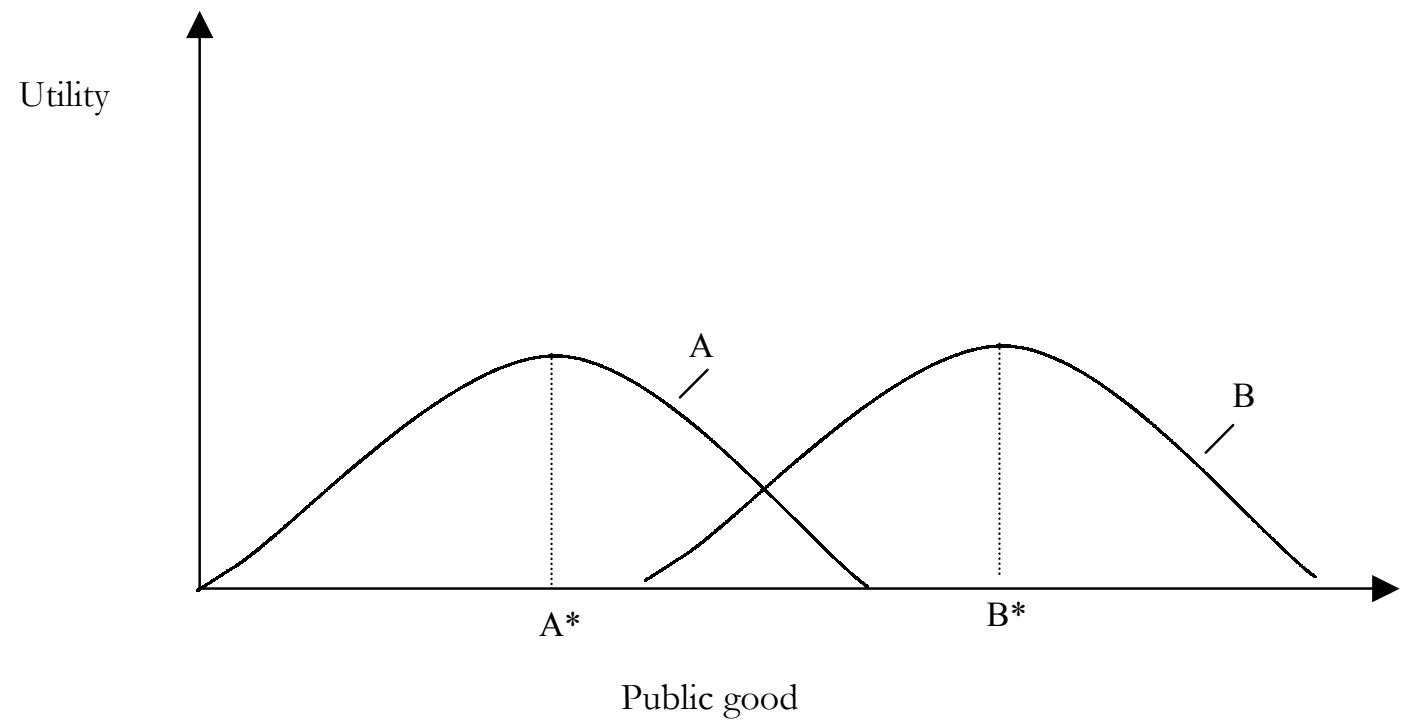

Figure 7: Ethnicity and Education provision in Western Kenya

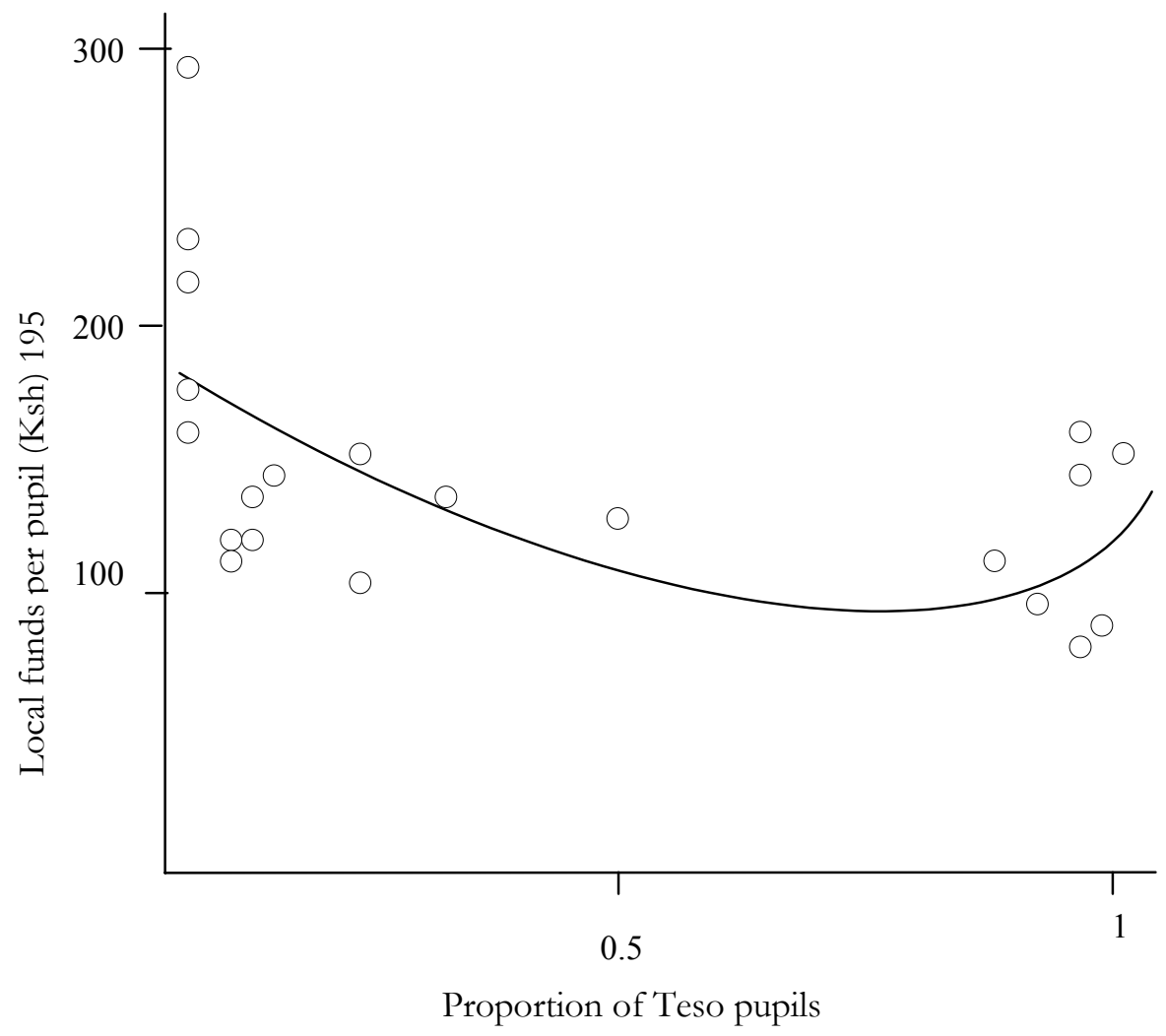

Source: Miguel, 2000 
Table 1: Dominant ethnic groups in 11 countries of Sub-Saharan Africa.

\begin{tabular}{|c|c|c|c|}
\hline Country & $\begin{array}{l}\text { Ethnic } \\
\text { Group }\end{array}$ & $\begin{array}{l}\text { Percent on } \\
\text { National } \\
\text { Population }\end{array}$ & $\begin{array}{l}\text { Head of state from } \\
\text { Ethnic Group }\end{array}$ \\
\hline Central African & M'baka & 7 & 1966-79 (Bokasa) \\
\hline Republic & Yakoma & 8 & 1980-93 (Kolingba) \\
\hline Cote d'Ivore & Baoule & 20 & $\begin{array}{l}\text { 1960-1999 } \\
\text { (Houphouet-Boigny ; Bedie) }\end{array}$ \\
\hline Ghana & Ashanti & 28 & $\begin{array}{l}\text { 1969-79 (Several) } \\
1982-2001 \text { (Rawlings)* }\end{array}$ \\
\hline Kenya & $\begin{array}{l}\text { Kikuyu } \\
\text { Kalenjin }\end{array}$ & $\begin{array}{l}21 \\
11\end{array}$ & $\begin{array}{l}\text { 1963-1978 (Kenyatta) } \\
\text { 1978-2002 (Moi) }\end{array}$ \\
\hline Mali & Bambara & 31 & 1968-91 (Traore) \\
\hline Namibia & Ovambo & 46 & 1990- present (Nujoma) \\
\hline Niger & Djerma-Songhai & 24 & 1960-93 (Lule; Binaira) \\
\hline Rwanda & Hutu & 90 & 1962-94 (Kayibanda; Habyarimana) \\
\hline Senegal & Serer & 19 & 1960- present (Senghor; Diouf) \\
\hline Uganda & Baganda & 16 & 1979 (Lule; Binaira) \\
\hline Zambia & Bemba & 15 & 1964-91 (Kaunda) \\
\hline
\end{tabular}

${ }^{*}$ Rawlings is non-Ashanti; his wife is a member of the Ashanti royal family.

Source: Brockerhoff and Hewett (1998) (attributed to Morrisson, Mitchell and Paden 1989). Note that a few changes were made in the table to make it current. 
Table 2: Characteristics of ethnic groups in 11 countries (in percent) ${ }^{a}$

\begin{tabular}{|c|c|c|}
\hline $\begin{array}{l}\text { Country and } \\
\text { Survey year }\end{array}$ & $\begin{array}{c}\text { Women } \\
\text { Attended } \\
\text { School } \\
\end{array}$ & $\begin{array}{l}\text { Children Received } \\
\text { Complete } \\
\text { Immunization }^{\mathrm{b}}\end{array}$ \\
\hline \multicolumn{3}{|c|}{ Central African republic 1994/95 } \\
\hline Yakoma & $71.3^{* *}$ & $63.3^{* *}$ \\
\hline M’baka & $67.9^{* *}$ & 37.7 \\
\hline All other & 44.5 & 36.4 \\
\hline \multicolumn{3}{|c|}{ Cote d'Ivore, 1994} \\
\hline Baoule & $49.5^{* *}$ & $46.3^{* *}$ \\
\hline All other & 39.0 & 34.8 \\
\hline \multicolumn{3}{|c|}{ Ghana, 1993} \\
\hline Ashanti & $84.1^{* *}$ & $60.8^{* *}$ \\
\hline All other & 60.4 & 49.7 \\
\hline \multicolumn{3}{|c|}{ Kenya, 1993} \\
\hline Kikuyu & $90.5^{* *}$ & $89.2^{* *}$ \\
\hline Kalenjin & 80.1 & 72.9 \\
\hline All other & 80.7 & 70.7 \\
\hline \multicolumn{3}{|c|}{ Mali, 1995/96 } \\
\hline Bambara & $20.6^{*}$ & $37.8^{* *}$ \\
\hline All other & 18.0 & 31.3 \\
\hline \multicolumn{3}{|c|}{ Namibia, 1992} \\
\hline Ovambo & $88.2^{* *}$ & $60.3^{* *}$ \\
\hline European & $97.2^{* *}$ & $61.4^{* *}$ \\
\hline All other & 78.4 & 46.9 \\
\hline \multicolumn{3}{|c|}{ Niger, 19992} \\
\hline Djerma-Songhai & $16.8^{* *}$ & $22.8^{* *}$ \\
\hline All other & 8.9 & 13.9 \\
\hline \multicolumn{3}{|c|}{ Rwanda, 1992} \\
\hline Hutu & $60.3^{*}$ & $78.3^{*}$ \\
\hline Tutsi & $80.2^{* *}$ & 84.9 \\
\hline \multicolumn{3}{|c|}{ Senegal, 1992,1993 } \\
\hline Serer & 25.3 & $63.4^{* *}$ \\
\hline All other & 26.9 & 49.0 \\
\hline \multicolumn{3}{|c|}{ Uganda, 1995} \\
\hline Baganda & $95.1^{\text {** }}$ & $62.5^{* *}$ \\
\hline All other & 64.3 & 49.3 \\
\hline \multicolumn{3}{|c|}{ Zambia, 1992} \\
\hline Bemba & $89.0^{* *}$ & 65.4 \\
\hline All other & 81.0 & 64.5 \\
\hline
\end{tabular}

$* p \leq 0.05,{ }^{*} * p \leq 0.01$

${ }^{a}$ Statistics are derived from women ages 15-49. bBased on children ages12-59 months. Received BCG, measles, DPT 1-3, and polio 1-3 immunisation. 
Table 3: Rural community characteristics of ethnic group members in six countries

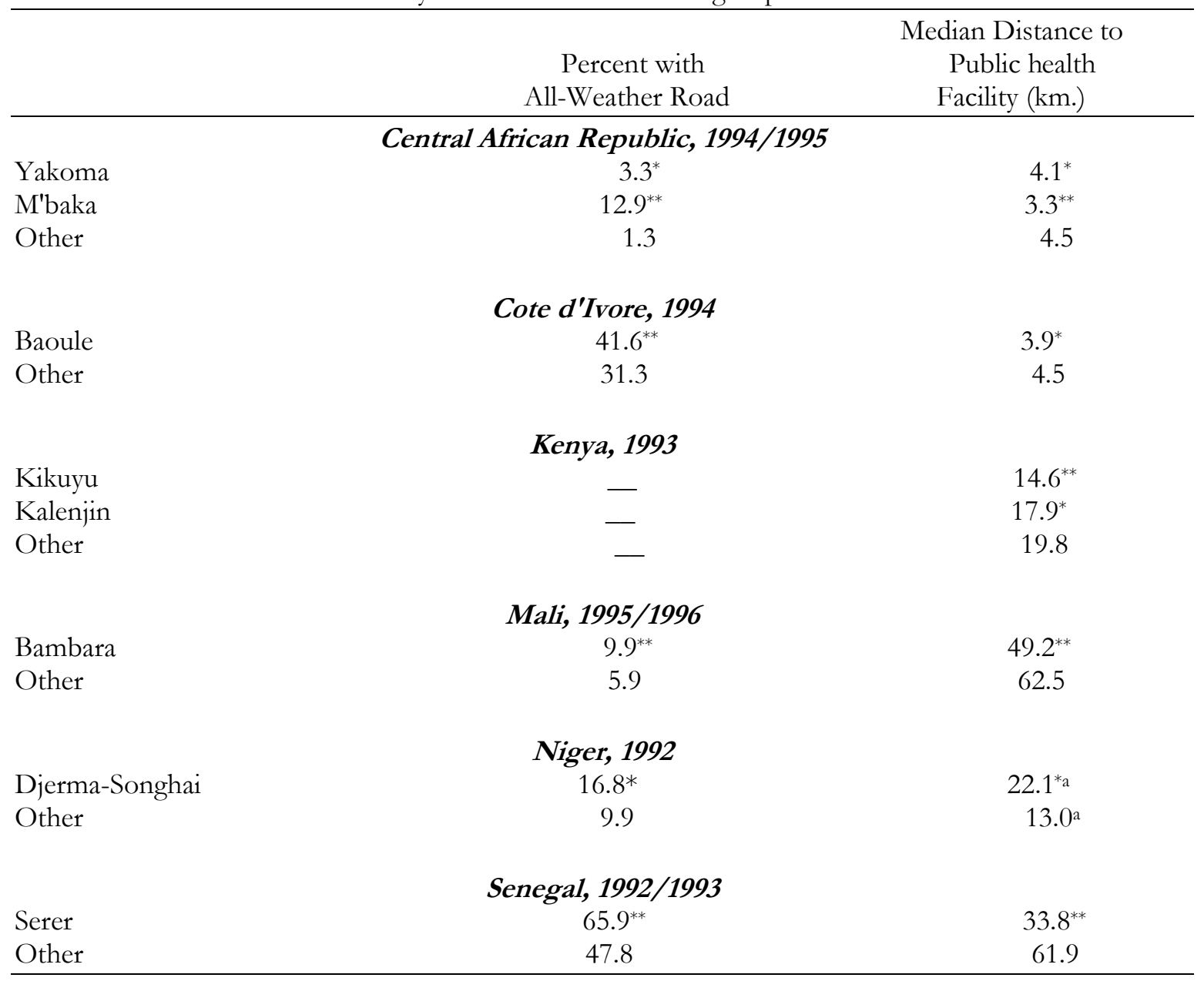

$* p \leq 0.05,{ }^{* *} p \leq 0.01$

aPercent living within 50 kilometres of a public health facility. 
Table 4: Ethnicity and provision of patronage goods-Kenya

\begin{tabular}{lccc}
\hline & $\begin{array}{c}\text { Last cabinet } \\
\text { (Kenyatta) } \\
1978\end{array}$ & $\begin{array}{c}\text { First cabinet } \\
\text { (Moi) } \\
1982\end{array}$ & $\begin{array}{c}\text { Second cabinet } \\
\text { (Moi) } \\
1988\end{array}$ \\
\hline $\begin{array}{l}\text { Number of } \\
\text { members }\end{array}$ & 22 & 28 & 34 \\
$\begin{array}{l}\% \text { of members of } \\
\begin{array}{l}\text { Kenyatta's cabinet } \\
\text { retained } \\
\% \text { of members of }\end{array}\end{array}$ & - & 35 & 14 \\
$\begin{array}{l}\text { Kenyatta's tribe } \\
\text { retained }\end{array}$ & - & 14 & 3 \\
\hline
\end{tabular}

Table 5: Burundi: ETHNIC DISPARITIES IN PUBLIC SECTOR CIVIL SERVICE POSTS IN 1997

\begin{tabular}{|l|l|l|l|}
\hline & Hutu & Tutsi & Twa \\
\hline Office of the president & 1 & 98 & 0 \\
\hline Central Committee of Single Party & 2 & 50 & 0 \\
\hline Administration of single party & 3 & 52 & 0 \\
\hline Ministers & 5 & 13 & 0 \\
\hline Cabinet directors & 1 & 17 & 0 \\
\hline Ministry Permanent Secretaries & 0 & 40 & 0 \\
\hline Province Governors & 2 & 13 & 0 \\
\hline Ambassadors & 1 & 21 & 0 \\
\hline Embassy Senior Diplomats & 0 & 88 & 0 \\
\hline Army Barrack Commanders & 0 & 20 & 0 \\
\hline Army Officers & 2 & 398 & 0 \\
\hline Army Sergeant and Privates & 30 & 11970 & 0 \\
\hline State Owned Companies Directors & 5 & 252 & 0 \\
\hline Hospital Directors & 1 & 19 & 0 \\
\hline University Lecturers & 10 & 80 & 0 \\
\hline Secondary Schools Directors and Inspectors & 6 & 89 & 0 \\
\hline Justice Prosecutors & 0 & 66 & 0 \\
\hline Magistrates & 5 & 92 & 0 \\
\hline Court Presidents & 1 & 7 & 0 \\
\hline Judiciary Police Officers and Inspectors & 0 & 400 & 0 \\
\hline
\end{tabular}

Source: Ntibazonkiza, R. (1993) in http://www.dse.de/ef/business/nkurunzi.htm

Note from the author suggest that the statistics may exaggerate the extent of Tutsi domination. Nevertheless the fact that the Tutsi dominate is unquestionable and, at the very least, this is the message the figures should convey. 


\begin{tabular}{|l|l|l|l|l|}
\hline $\begin{array}{l}\text { Table 6: Burundi: ETHNIC AND REGIONAL DISTRIBUTION OF MANAGERS OF PUBLIC } \\
\text { CORPORATIONS }\end{array}$ & Hutus & Twa & TOTAL \\
\hline $\begin{array}{l}\text { ETHNIC } \\
\text { GROUP }\end{array}$ & Tutsis & & & \\
$\begin{array}{l}\text { REGION OF } \\
\text { ORIGIN }\end{array}$ & & 3 & 0 & 63 \\
\hline Bururi province & 60 & 8 & 0 & 37 \\
\hline $\begin{array}{l}\text { Remaining } \\
\text { provinces }\end{array}$ & 29 & 11 & 0 & 100 \\
\hline TOTAL & 89 & \multicolumn{3}{|l|}{} \\
\hline
\end{tabular}

Source: Raw data from ICG 
